\title{
Outcome after depot gonadotrophin-releasing hormone agonist treatment for central precocious puberty: effects on body mass index and final height
}

\author{
C Traggiai, P Polo Perucchin, K Zerbini, R Gastaldi, P De Biasio ${ }^{1}$ and R Lorini \\ Departments of Paediatrics and ${ }^{1}$ Obstetrics and Gynaecology, University of Genoa, IRCCS G. Gaslini, L.go G. Gaslini 5, 16147 Genoa, Italy
}

(Correspondence should be addressed to R Lorini; Email: renatalorini@ospedale-gaslini.ge.it)

In their interesting paper, Arrigo et al. (1) investigated longitudinally body mass index (BMI) evolution and prevalence of obesity in girls with idiopathic central precocious puberty $(\mathrm{CPP})$ who were treated with luteinizing hormone-releasing hormone (LHRH) analogs (LHRHa) for at least 2 years. They demonstrated that suppression of the pituitary-gonadal axis function was accompanied by a significant decrease in being overweight. They observed that girls with CPP are frequently obese at diagnosis, suggesting that the pretreatment increase in BMI is due to pubertal hormonal changes and secondary changes in body fat, rather than being a result of CPP (1).

We have retrospectively reviewed 29 female patients with idiopathic CPP. The main criteria for diagnosis of idiopathic CPP were (1) onset of breast development and/or menses before 8 years of age, (2) pubertal luteinizing hormone (LH) response to exogenous LHRH (LH peak > $10 \mathrm{IU} / \mathrm{l}$ ), (3) no evidence of hypothalamo-pituitary lesions at magnetic resonance imaging and (4) no additional conditions that might affect BMI. Predicted height was calculated using a computerized Byley-Pinneau method (2). We assessed height SDS, BMI and BMI SDS (3) before, 1 year after the beginning of therapy, at the end of therapy and 2.5 years after the end of therapy. A group of 45 healthy girls with normal onset of puberty was matched for age or for pubertal stage. Statistical analysis was performed with $\chi^{2}$ test and paired sample $t$-test ( $P$ was considered significant if $<0.01$ ).

Auxological findings (height SDS, BMI and BMI SDS) and statistical analysis are shown in Table 1 . The mean period of treatment was 2.1 years (range 1.93.1 years). The mean age of menarche in 19 out of 29 girls was 12.1 years (range 10.4-13.7 years). Eighteen patients complained of side-effects: 16 girls had headache (11 out of 16 isolated headache, two out of 16 with spotting, one out of 16 with joint pain, one out of 16 with increased appetite and one out of 16 with abdominal pain), one girl had isolated spotting and one girl had isolated increased appetite. The final height of the treated girls was in the normal range for parental target height. The reproduc- tive axis appeared to have returned to normal in our patients, with normal menses in 19 out of 30 girls who had already had menarche at the time of our study.

In contrast to the study by Arrigo et al. (1) showing a reduction in baseline BMI under LHRHa therapy in girls with CPP, we found an increasing trend in BMI after the first year of therapy, and this did not change after therapy was stopped. With regard to BMI SDS, few changes were observed during the first year of therapy, while an increasing trend was observed at the end of therapy and a complete recovery after 2.5 years of the end of therapy. Nevertheless, in both girls with CPP and the control group, the mean BMI increased; in fact the value in the patients was as much as in the control group during therapy and at the end of therapy. Mean BMI SDS, different in the two groups, was significantly higher in the patients at the end of therapy than in controls, suggesting that the difference was due to the treatment. The data available in the literature on the effects of LHRHa treatment on BMI are few and controversial. Excessive weight gain can occur by various mechanisms: menopausal-like phenomena, or the influence of LHRHa on hypothalamic and/or leptin-mediated control of body weight (4). Some authors have highlighted the fact that obesity is frequent among children with CPP, but does not appear to be related to the longterm pituitary-gonadal suppression induced by LHRHa therapy $(5-7)$. On the other hand, Feuillan et al. (8) showed the association of both CPP and LHRHa with obesity in patients who had increased BMI at initial presentation and during therapy; this condition persisted after discontinuation of therapy and progresses to frank obesity (8).

\section{References}

1 Arrigo T, De Luca F, Antoniazzi F, Galluzzi F, Segni M, Rosano M, Messina MF \& Lombardo F. Reduction of baseline body mass index under gonadotropin-suppressive therapy in girls with idiopathic precocious puberty. European Journal of Endocrinology 2004 $150533-537$. 
Table 1 Auxological findings and statistical analyses in girls with CPP $(n=29)$ and controls $(n=45)$ at diagnosis, after 1 year of therapy, at the end of therapy and 2.5 years after the end of therapy.

\begin{tabular}{|c|c|c|c|c|c|c|c|c|c|c|}
\hline \multirow[b]{2}{*}{ Time } & \multicolumn{2}{|c|}{$\begin{array}{l}\text { Mean chronological } \\
\text { age (range) }\end{array}$} & \multicolumn{2}{|c|}{ Mean height SDS (range) } & \multicolumn{3}{|c|}{ Mean BMI (range) } & \multicolumn{3}{|c|}{ Mean BMI SDS (range) } \\
\hline & CPP & Controls & CPP & Controls & CPP & Controls & $P$ & CPP & Controls & $P$ \\
\hline )iagnosis & $\begin{array}{c}7.9 \\
(6.6-8.6)\end{array}$ & $\begin{array}{c}9.2 \\
(6.5-10.5)\end{array}$ & $\begin{array}{c}1.3 \\
(-0.5 /+44)\end{array}$ & $\begin{array}{c}0.66 \\
(-1.35 /+3.97)\end{array}$ & $\begin{array}{c}18.5 \\
(15.5-23.7)\end{array}$ & $\begin{array}{c}19.7 \\
(16.2-24.2)\end{array}$ & 0.085 & $\begin{array}{c}1.7 \\
(-0.4 /+5.7)\end{array}$ & $\begin{array}{c}2.1 \\
(-1.1 /+4.69)\end{array}$ & 0.029 \\
\hline After 1 year & $\begin{array}{c}8.8 \\
(7.6-9.6)\end{array}$ & $\begin{array}{c}9.4 \\
(8.2-11.6)\end{array}$ & $\begin{array}{c}1.4 \\
(-0.9 /+4)\end{array}$ & $\begin{array}{c}0.9 \\
(-1.46 /+3.97)\end{array}$ & $\begin{array}{c}20 \\
(12.8-24.4)\end{array}$ & $\begin{array}{c}19.4 \\
(15-24.7)\end{array}$ & 0.014 & $\begin{array}{c}1.8 \\
(-0.9 /+4.6)\end{array}$ & $\begin{array}{c}1.6 \\
(-1.38 /+4.69)\end{array}$ & 0.011 \\
\hline End & $\begin{array}{c}11 \\
(9.6-11.7)\end{array}$ & $\begin{array}{c}11.3 \\
(10.3-13)\end{array}$ & $\begin{array}{c}1.2 \\
(-2 /+4)\end{array}$ & $\begin{array}{c}0.9 \\
(-1.46 /+3.97)\end{array}$ & $\begin{array}{c}21.3 \\
(17.6-29.3)\end{array}$ & $\begin{array}{c}20.1 \\
(14.2-25.5)\end{array}$ & 0.011 & $\begin{array}{c}2.2 \\
(+0.1 /+6)\end{array}$ & $\begin{array}{c}1.5 \\
(-1.38 /+4.47)\end{array}$ & 0.002 \\
\hline $\begin{array}{l}\text { After } \\
2.5 \text { years }\end{array}$ & $\begin{array}{c}13.5 \\
(12.1-14.2)\end{array}$ & $\begin{array}{c}14.3 \\
(11.5-17.1)\end{array}$ & $\begin{array}{c}0.4 \\
(-2.3 /+4)\end{array}$ & $\begin{array}{c}-0.1 \\
(-1.76 /+1.84)\end{array}$ & $\begin{array}{c}21.7 \\
(17-29.3)\end{array}$ & $\begin{array}{c}21.8 \\
(15.9-29.4)\end{array}$ & 0.078 & $\begin{array}{c}1.6 \\
(-0.1 /+6)\end{array}$ & $\begin{array}{c}1 \\
(-1.22 /+4.42)\end{array}$ & 0.067 \\
\hline
\end{tabular}

2 Greulich WW \& Pyle SI. Radiographic Atlas of Skeletal Development of the Hand and Wrist, edn 2. Stanford, CA: Stanford University Press, 1959.

3 Rolland-Cachera MF, Cole TJ, Sempe M, Tichet J, Rossignol C \& Charraud A. Body mass index variations: centiles from birth to 87 years. European Journal of Clinical Nutrition $19914513-21$.

4 Kanbur NO, Derman O \& Kinik E. Prevalence of obesity in adolescents and the impact of sexual maturation stage on body mass index in obese adolescents. International Journal of Adolescent Medicine and Health 200214 61-65.

5 Chiumello G, Brambilla P, Guarneri MP, Russo G, Manzoni P \& Sgaramella P. Precocious puberty and body composition: effects of $\mathrm{GnRH}$ analog treatment. Journal of Pediatric Endocrinology and Metabolism. 200013 (Suppl 1) 791-794.

6 Palmert MR, Mansfield MJ, Crowley WF Jr, Crigler JF Jr, Crawford JD \& Boepple PA. Is obesity an outcome of gonadotropin-releasing hormone agonist administration? Analysis of growth and body composition in 110 patients with central precocious puberty. Journal of Clinical Endocrinology and Metabolism 199984 4480-4488.

7 Heger S, Partsch CJ \& Sippell WG. Long-term outcome after depot gonadotropin-releasing hormone agonist treatment of central precocious puberty: final height, body proportions, body composition, bone mineral density, and reproductive function. Journal of Clinical Endocrinology and Metabolism 199984 4583-4590.

8 Feuillan PP, Jones JV, Barnes K, Klein KO \& Cutler GB Jr. Follow-up of children and young adults after GnRH-agonist therapy for central precocious puberty. Journal of Endocrinological Investigation $200124734-736$

Received 30 May 2005

Accepted 1 June 2005 